\title{
Cow Urine for Enhancement of Biogas Production and Fertilizer Quality of Biogas Slurry
}

\author{
M. R. Fardous ${ }^{1}$, M. S. Nasrin ${ }^{2}$, M. E. Shakil ${ }^{1}$, M. S. Islam ${ }^{1}$, M. A. Hoque $^{2}$, M. N. Islam ${ }^{1 *}$ \\ ${ }^{1}$ Department of Chemistry, University of Rajshahi, Rajshahi-6205, Bangladesh \\ ${ }^{2}$ Department of Biochemistry and Molecular Biology, University of Rajshahi, Rajshahi-6205, \\ Bangladesh
}

Received 4 October 2019, accepted in final revised form 5 December 2019

\begin{abstract}
To explore the potency of cow urine on biogas production and fertilizer quality of the biogas slurries, six experimental trials, $\mathrm{T}_{0}\left(50 \% \mathrm{CD}: 50 \%\right.$ Water) as control, $\mathrm{T}_{1}(10 \% \mathrm{CD}$ : $90 \% \mathrm{CU}), \mathrm{T}_{2}(20 \% \mathrm{CD}: 80 \% \mathrm{CU}), \mathrm{T}_{3}(30 \% \mathrm{CD}: 70 \% \mathrm{CU}), \mathrm{T}_{4}(40 \% \mathrm{CD}: 60 \% \mathrm{CU})$ and $\mathrm{T}_{5}$ (50\% CD:50\% CU) were constructed by mixing cow dung (CD) and cow urine (CU). Cumulative gas volume was estimated for 30 days and the physicochemical properties of the slurries were evaluated. The cumulative gas volume of three trials $\left(T_{3}, T_{4}\right.$ and $\left.T_{5}\right)$ was higher than control $\left(\mathrm{T}_{0}\right)$ and $\mathrm{T}_{5}$ showed maximum (28\% over the control). Moreover, all of the trials except one $\left(T_{1}\right)$ showed higher gas yield than control $\left(T_{0}\right)$ of which maximum conversion of volatile solid (VS) to gas was obtained in $\mathrm{T}_{3}$. $\mathrm{pH}$ of the amended samples were above 7.0 (pH 7.00-7.42). Conductivity of the samples also increases (1.94-13.40 mS $\mathrm{cm}^{-1}$ ) with the increase in cow urine percentage. With respect to macronutrient $(\mathrm{N}, \mathrm{P}, \mathrm{K})$ cow urine amended samples can be considered superior to the control one. Moreover, $\mathrm{C} / \mathrm{N}$ ratio of all the amended samples were below 15 (4.7-14.0) and thus these are suitable for agronomic uses.
\end{abstract}

Keywords: Cow urine; Biogas; Biogas slurry; Organic fertilizer; Macronutrients.

(C) 2020 JSR Publications. ISSN: 2070-0237 (Print); 2070-0245 (Online). All rights reserved. doi: http://dx.doi.org/10.3329/jsr.v12i1.43031

J. Sci. Res. 12 (1), 135-144 (2020)

\section{Introduction}

Biogas production is an environmental friendly process which utilizes anaerobic digestion of the organic waste. This process offers significant advantages over most of the other waste treatment processes. Moreover, biogas technology helps to reduce the greenhouse gas emission and to afford organic fertilizer as by-product [1]. The main product biogas is a renewable energy resource, while the by-product, i.e., biogas slurry, can be utilized as fertilizer due to its high plant nutrient content [2].

As an agricultural country, Bangladesh is blessed with plenty of organic waste which has been used partly for extracting energy by generating biogas. However, the amount of

\footnotetext{
* Corresponding author: mnurulchem@gmail.com
} 
organic materials currently used for biogas production is limited and new substrates as well as new effective technologies are therefore needed to facilitate the growth of the biogas industry in Bangladesh and all over the world.

Major developments have been made during the last decades regarding the utilization of lignocellulosic biomass. The major challenge in anaerobic digestion process is to overcome the rate limiting step, methanogenesis. Several high rate anaerobic reactor systems, such as up flow anaerobic sludge blanket (UASB) reactor, membrane bioreactor (MBR) etc. and the application of membrane technologies have been developed to overcome the shortcomings encountered [3]. Besides these efforts, co-digestion has recently taken much attention since it is one of the interesting ways of improving the yield of anaerobic digestion. A successful co-digestion is not simply a digestion of several waste streams treated at the same time. In fact, biogas production and the stability of the process are highly dependent on waste composition, process conditions, and the activity of microbial community in the system [4]. Carbon to nitrogen $(\mathrm{C} / \mathrm{N})$ ratio has been identified as the key parameter for improving the digestion of substrates. The average $\mathrm{C} / \mathrm{N}$ ratio of 20-30 has been stated as optimum for maximum yield of biogas and corresponding methane in it [5].

Addition of certain substances increases the output of gas from cow dung. These substances include chemicals, ground nut cake, urine etc. [6]. Therefore, any available cheap organic raw material rich in nitrogen can be mixed with cattle dung to increase the gas production. Cow urine may be considered in this regard. Significant amount of urine discharged from each cattle drains out and pollutes the environment. Generally $\mathrm{C} / \mathrm{N}$ ratio of urine is lower than cow dung i.e. urine is rich in nitrogen which may enhance the gas production rate if mixed with cow dung at a certain proportion. $\mathrm{pH}$ of cattle urine also favors the gas production in anaerobic process. Moreover, extract of biogas slurry may be used as pest repellent as fermented cattle urine is rich in chloride, sulphate and nitrite [7].

In the present study, a varying proportion of cow dung and cow urine has been used for biogas production to investigate the effect of cow urine on biogas production and the quality of its slurry as an organic fertilizer.

\section{Experimental}

\subsection{Materials}

All chemicals used in analysis were of analytical grade. Redistilled and deionized water were used for solution preparation. Working solutions were prepared by sequential dilution of each standard solution with ultrapure water. The substrate cow dung and cow urine were collected from a local farm located at Meherchandi, Motihar, Rajshahi, Bangladesh. 


\subsection{Methods}

To investigate the effect of cow urine on biogas production and the quality of its slurry as an organic fertilizer, daily gas production was measured and the slurry thus obtained was investigated for its physico-chemical properties.

\subsubsection{Experimental setup for biogas production}

For biogas production, six experimental trials $\mathrm{T}_{0}, \mathrm{~T}_{1}, \mathrm{~T}_{2}, \mathrm{~T}_{3}, \mathrm{~T}_{4}$ and $\mathrm{T}_{5}$ were constructed by mixing cow dung (CD) and cow urine (CU) or water for maintaining the requisite composition as shown in Table 1.

Table 1. Composition of substrates for biogas production in different trials.

\begin{tabular}{cccccc}
\hline Trial & $\begin{array}{c}\text { Wt. of } \\
\text { CD/g }\end{array}$ & $\begin{array}{c}\text { Vol. of } \\
\text { CU/mL }\end{array}$ & $\begin{array}{c}\text { Vol. of } \\
\text { water/mL }\end{array}$ & $\begin{array}{c}\text { \% ratio } \\
(\mathrm{CD} / \mathrm{CU})\end{array}$ & $\begin{array}{c}\text { Moisture } \\
\text { content }(\%)\end{array}$ \\
\hline $\mathrm{T}_{0}$ & 1000 & 0 & 1000 & $50: 50^{*}$ & 88.17 \\
$\mathrm{~T}_{1}$ & 200 & 1800 & 0 & $10: 90$ & 96.72 \\
$\mathrm{~T}_{2}$ & 400 & 1600 & 0 & $20: 80$ & 94.40 \\
$\mathrm{~T}_{3}$ & 600 & 1400 & 0 & $30: 70$ & 92.10 \\
$\mathrm{~T}_{4}$ & 800 & 1200 & 0 & $40: 60$ & 89.81 \\
$\mathrm{~T}_{5}$ & 1000 & 1000 & 0 & $50: 50$ & 87.53 \\
\hline
\end{tabular}

${ }^{*}$ For control $\mathrm{T}_{0}$, water was used instead of $\mathrm{CU}$

Each of the mixtures was taken in $5 \mathrm{~L}$ suction flask for digestion. Seeding materials were added into the raw materials for its rapid fermentation. Aspirator bottle with $1.0 \mathrm{M}$ $\mathrm{NaOH}$ solution was used for washing the gas to remove $\mathrm{CO}_{2}, \mathrm{SO}_{2}$ and $\mathrm{H}_{2} \mathrm{~S}$. The $\mathrm{NaOH}$ solution displaced by the gas was collected in another aspirator bottle.

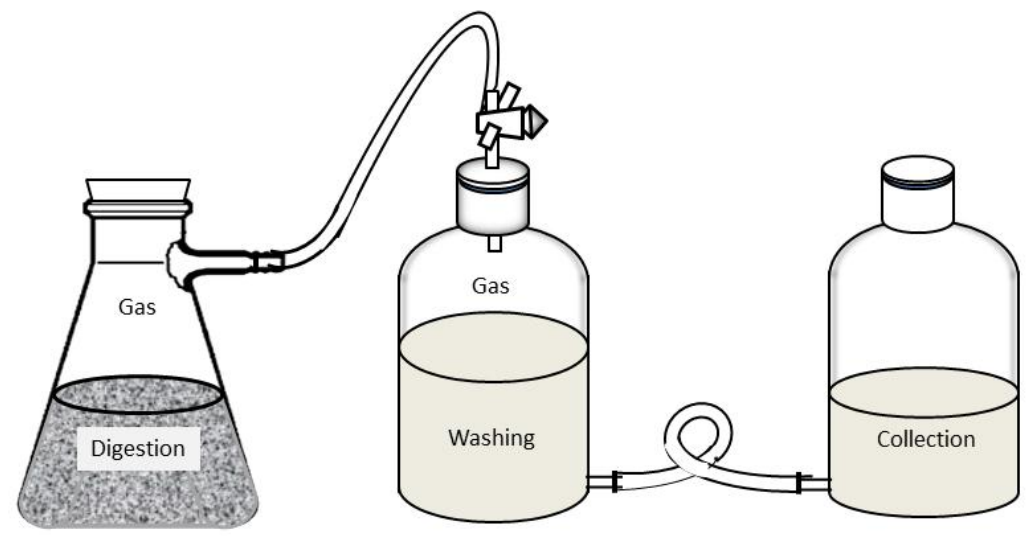

Fig. 1. Experimental setup of biogas generation. 
The digester flask, washing bottle and collector bottle were connected in series for different experiments shown in Fig. 1. The daily gas production was recorded for 30 days.

\subsubsection{Determination of moisture, total solid and volatile solid}

Moisture content, total solid (TS) and volatile solid (VS) of fresh substrate were estimated by gravimetric method [8] by drying at $105^{\circ} \mathrm{C}$ for overnight and by complete combustion at $400^{\circ} \mathrm{C}$ for six hours. The moisture content and TS were calculated from fresh and oven dried mass of the sample. VS was calculated from oven dried and combusted mass of the sample.

\subsubsection{Determination of $p H$ and Electrical Conductivity (EC)}

Before analyzing, the liquid biogas slurry samples were diluted with deionized water to attain identical solid content to $\mathrm{T}_{1}$ as it was the minimum. $\mathrm{pH}$ of the samples were measured with the help of $\mathrm{pH}$ meter (Hanna Instruments, HI 2211). Before using, pH meter was calibrated according to manufacturer's instructions using the buffer at $\mathrm{pH} 4.00$ and 7.00. EC was measured by a conductivity meter (Jenway Conductivity Meter 4310). The conductivity meter was calibrated and cell constant was determined with $0.1 \mathrm{M}$ and $0.01 \mathrm{M}$ standard $\mathrm{KCl}$ solution.

\subsubsection{Determination of Total Organic Carbon (TOC)}

TOC was determined by loss-on-ignition method [9] that involves the heated destruction of all organic matter in the sample. A known weight of oven dried sample was placed in a ceramic crucible which was then heated at $400^{\circ} \mathrm{C}$ for $6 \mathrm{hr}$. in a muffle furnace [8]. The sample was then cooled in a desiccator and weighed. Organic matter (OM) content $\left(\mathrm{g} \mathrm{kg}^{-}\right.$ ${ }^{1}$ ) was calculated as the difference between the initial and final sample weights divided by the initial sample weight times 1000 . OM was multiplied by 0.5 to obtained TOC [10].

\subsubsection{Estimation of total nitrogen $\left(N_{\text {tot }}\right)$}

Total nitrogen was measured using modified Kjeldahl method [11]. $1.0 \mathrm{~g}$ of dried sample was digested at $320-370{ }^{\circ} \mathrm{C}$ with $0.7 \mathrm{~g}$ of copper sulphate, $1.5 \mathrm{~g}$ of $\mathrm{K}_{2} \mathrm{SO}_{4}$ and $30 \mathrm{~mL}$ of conc. $\mathrm{H}_{2} \mathrm{SO}_{4}(98 \%)$ in a Kjeldahl flask until the solution became clear. At the end of digestion, the solution was distilled with $35 \% \mathrm{NaOH}$ solution and the distillate was collected in excess $0.1 \mathrm{M} \mathrm{HCl}$ solution containing methyl red indicator. The excess $\mathrm{HCl}$ was titrated with $0.1 \mathrm{M} \mathrm{NaOH}$ solution. The amount of nitrogen in the sample was calculated from the required volume of $\mathrm{HCl}$ solution.

\subsubsection{Estimation of available phosphorus $\left(P_{\text {avail }}\right)$}

Available phosphorous was measured by the method described by Olsen et al. [12]. $5.0 \mathrm{~g}$ of dried sample was shaken with $100 \mathrm{~mL}$ of the $0.5 \mathrm{M} \mathrm{NaHCO}_{3}$ solution and 1 teaspoon 
carbon black to make the solution clear. The mixture was filtered using Whatman filter paper. The filtrates were analyzed following the reported method [13] using UV-visible spectrophotometer (UV-1800, SHIMADZU).

\subsubsection{Determination of exchangeable potassium $\left(K_{\text {exch }}\right)$}

$\mathbf{K}_{\text {exch }}$ was determined after extracting the sample using ammonium acetate [14] followed by analysis using Atomic Absorption Spectrophotometer (AAS).

\section{Results and Discussion}

\subsection{Cumulative gas production from different trials}

The cumulative gas volumes of different trials are shown in Table 2 and the data are presented in Fig. 2. Most of the observation period, the cumulative gas volume was of the order of $\mathrm{T}_{5}>\mathrm{T}_{4}>\mathrm{T}_{3}>\mathrm{T}_{0}>\mathrm{T}_{2}>\mathrm{T}_{1}$. As expected $\mathrm{T}_{1}(10 \% \mathrm{CD}: 90 \% \mathrm{CU})$ and $\mathrm{T}_{2}(20 \% \mathrm{CD}$ : $80 \% \mathrm{CU}$ ) showed lower gas production than control $\mathrm{T}_{0}(50 \% \mathrm{CD}: 50 \%$ water) due to less solid content. Although $\mathrm{T}_{4}$ and $\mathrm{T}_{3}$ have less solid content, their gas production is higher than the control one $\left(\mathrm{T}_{0}\right)$. The $\mathrm{C} / \mathrm{N}$ ratio in the organic material plays a crucial role in anaerobic digestion [15] and 20-30 is better for gas production [5]. Generally $\mathrm{C}: \mathrm{N}$ ratio of $\mathrm{CU}$ is relatively lower than $\mathrm{CD}$ due to high ammonia content that may enhance gas production by adjusting $\mathrm{C} / \mathrm{N}$ ratio to $20-30$.

Table 2. Cumulative volume of gas produced from different trials.

\begin{tabular}{ccccccc}
\hline & \multicolumn{7}{c}{ Volume of gas $/ \mathrm{mL}$} \\
\hline Time/Day & $\mathrm{T}_{0}$ & $\mathrm{~T}_{1}$ & $\mathrm{~T}_{2}$ & $\mathrm{~T}_{3}$ & $\mathrm{~T}_{4}$ & $\mathrm{~T}_{5}$ \\
\hline 5 & 2290 & 252 & 1045 & 2905 & 2305 & 3160 \\
10 & 5957 & 972 & 2850 & 8005 & 8195 & 10620 \\
15 & 10387 & 2202 & 6240 & 13975 & 15340 & 18475 \\
20 & 14962 & 2681 & 9250 & 17205 & 17890 & 20745 \\
25 & 17412 & 2816 & 11285 & 18415 & 19180 & 22060 \\
30 & 18146 & 2816 & 12430 & 19245 & 20100 & 23195 \\
\hline
\end{tabular}

Being rich in nitrogen the addition of cow urine has positive contribution to biogas production. As a result, a proportion of $50 \%$ cow dung and $50 \%$ cow urine $\left(\mathrm{T}_{5}\right)$ increased gas production about $28 \%$ over the control $\left(\mathrm{T}_{0}\right)$. 


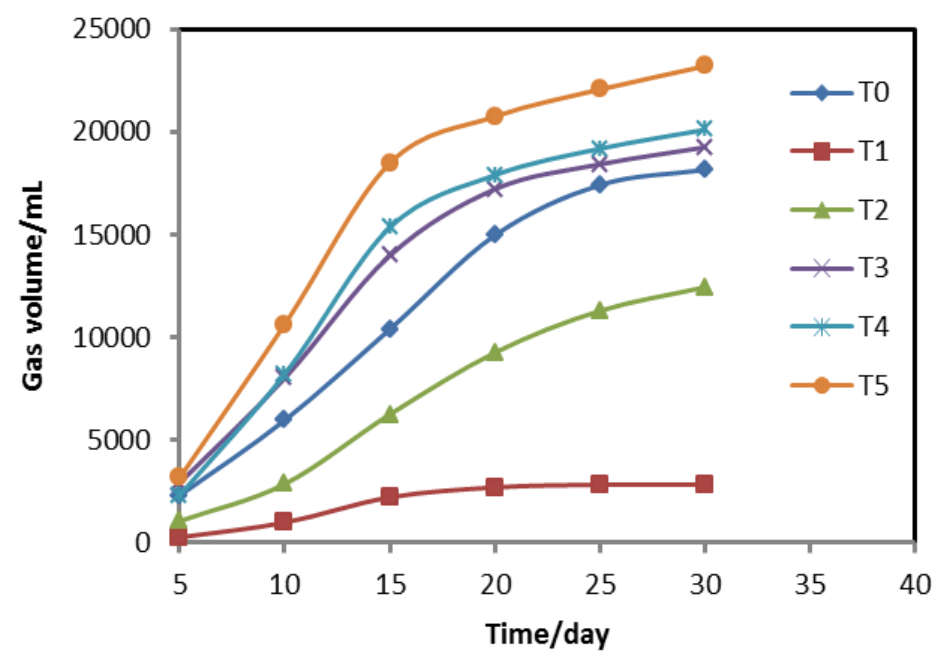

Fig. 2. Cumulative volume of gas produced from different trials.

\subsection{Gas yield in different trials}

The gas yields ( $\mathrm{L} \mathrm{kg}^{-1} \mathrm{VS}$ ) of different trials are shown in Table 3 and the data are presented in Fig. 3. The gas yield was the order of $T_{3}>T_{2}>T_{4}>T_{5}>T_{0}>T_{1}$. Interestingly all of the trails except one $\mathrm{T}_{1}(10 \% \mathrm{CD}: 90 \% \mathrm{CU})$ showed higher gas yield than control $\mathrm{T}_{0}(50 \%$ $\mathrm{CD}: 50 \%$ water). For co-digestion of cow dung with cow urine, the rate of solid conversion to gas was increased with the increase in VS reached maximum for $\mathrm{T}_{3}(30 \% \mathrm{CD}: 70 \% \mathrm{CU})$ and then decreased. Thus, the composition of $\mathrm{T}_{3}$ can be considered as ideal for maximum conversion of VS to gas.

Table 3. Moisture content, TS and VS of fresh substrates and gas yield in different trials.

\begin{tabular}{cccccc}
\hline Trial & $\begin{array}{c}\text { Moisture } \\
(\%)\end{array}$ & $\begin{array}{c}\text { TS } \\
(\%)\end{array}$ & $\begin{array}{c}\text { VS } \\
(\%)\end{array}$ & $\begin{array}{c}\text { Total gas } \\
\text { volume/L }\end{array}$ & $\begin{array}{c}\text { Gas yield } \\
/\left(\mathrm{L} \mathrm{kg}^{-1} \mathrm{VS}\right)\end{array}$ \\
\hline $\mathrm{T}_{0}$ & 88.17 & 11.83 & 9.37 & 18.146 & 96.8 \\
$\mathrm{~T}_{1}$ & 96.72 & 3.28 & 2.60 & 2.816 & 54.2 \\
$\mathrm{~T}_{2}$ & 94.4 & 5.6 & 4.44 & 12.430 & 140.1 \\
$\mathrm{~T}_{3}$ & 92.1 & 7.9 & 6.26 & 19.245 & 153.8 \\
$\mathrm{~T}_{4}$ & 89.81 & 10.19 & 8.07 & 20.100 & 124.5 \\
$\mathrm{~T}_{5}$ & 87.53 & 12.47 & 9.88 & 23.195 & 117.4 \\
\hline
\end{tabular}




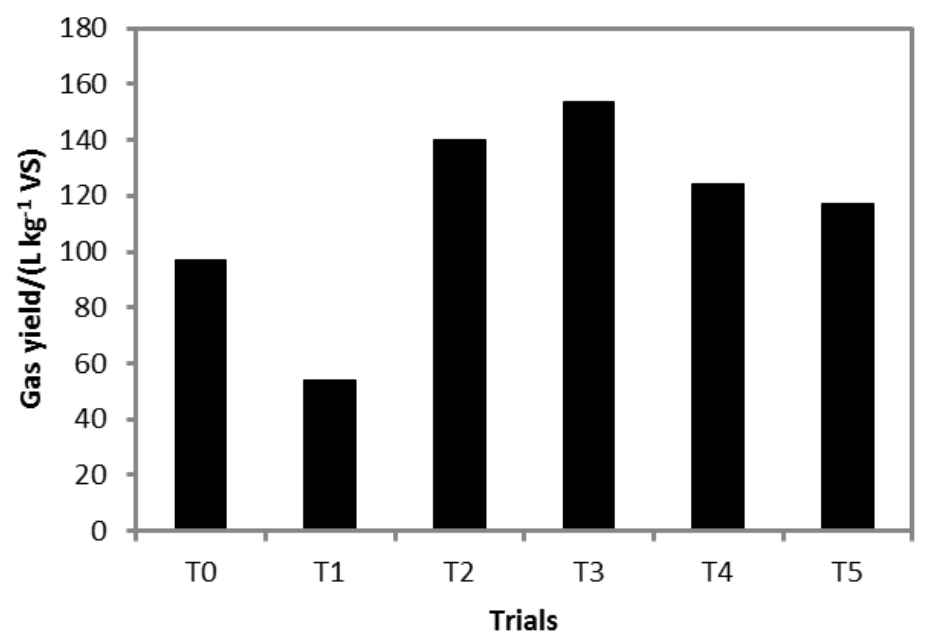

Fig. 3. Gas yield in different trials.

\section{3. $p H$ and conductivity}

$\mathrm{pH}$ of the mixtures was in the ranges of $6.80-7.42$ (Table 4). $\mathrm{pH}$ in different samples was in the order, $\mathrm{T}_{1}>\mathrm{T}_{2}>\mathrm{T}_{3}>\mathrm{T}_{4}>\mathrm{T}_{5}>\mathrm{T}_{0}$. It indicates that $\mathrm{pH}$ in the biogas slurry increases with the increase in urine of the biogas substrate due to presence of ammonia in urine. The optimum uptake of most nutrients occurs at a soil $\mathrm{pH}$ near neutral. The availability of most macronutrients (nitrogen, phosphorus, potassium, sulfur, calcium, and magnesium) decreases as soil acidity increases [16]. As the $\mathrm{pH}$ values of the biogas slurries are near 7.0, they can be considered as good soil amendments. Moreover, $\mathrm{T}_{1}-\mathrm{T}_{4}$ can be used for correcting $\mathrm{pH}$ of acidic soils. Conductivity of the mixtures was in the ranges of 1.36-4.00 $\mathrm{mS} \mathrm{cm}{ }^{-1}$ and was in the order, $\mathrm{T}_{1}>\mathrm{T}_{2}>\mathrm{T}_{3}>\mathrm{T}_{4}>\mathrm{T}_{5}>\mathrm{T}_{0}$ (Table 4, Fig. 4).

Table 4. $\mathrm{pH}, \mathrm{EC}$ and chemical compositions $\left(\mathrm{mg} \mathrm{g}^{-1}\right)$ of biogas slurries of different trials.

\begin{tabular}{cccccccc}
\hline Trials & $\mathrm{pH}$ & $\mathrm{EC} /\left(\mathrm{mS} \mathrm{cm}^{-1}\right)$ & $\mathrm{TOC}$ & $\mathrm{N}_{\text {tot }}$ & $\mathrm{P}_{\text {avail }}$ & $\mathrm{K}_{\text {exch }}$ & $\mathrm{C} / \mathrm{N}$ ratio \\
\hline $\mathrm{T}_{\mathrm{o}}$ & 6.80 & 1.36 & 359.0 & 18.09 & 2.27 & 10.92 & 19.8 \\
$\mathrm{~T}_{1}$ & 7.42 & 13.40 & 245.5 & 52.00 & 3.86 & 37.44 & 4.7 \\
$\mathrm{~T}_{2}$ & 7.38 & 4.00 & 288.6 & 44.37 & 1.82 & 26.52 & 6.5 \\
$\mathrm{~T}_{3}$ & 7.14 & 2.75 & 324.7 & 29.34 & 1.84 & 28.82 & 11.1 \\
$\mathrm{~T}_{4}$ & 7.06 & 2.15 & 328.9 & 27.19 & 1.68 & 18.72 & 12.1 \\
$\mathrm{~T}_{5}$ & 7.00 & 1.94 & 331.8 & 23.72 & 1.63 & 16.38 & 14.0 \\
\hline
\end{tabular}

It indicates that conductivity in the biogas slurry increases with the increase in urine as fermented cow urine is rich in different types of electrolyte [7]. Conductivity of solution indicates the presence of water soluble metal ions, including plant nutrients. Thus, utilization of cow urine in biogas production yields more nutrient rich biogas slurry. 


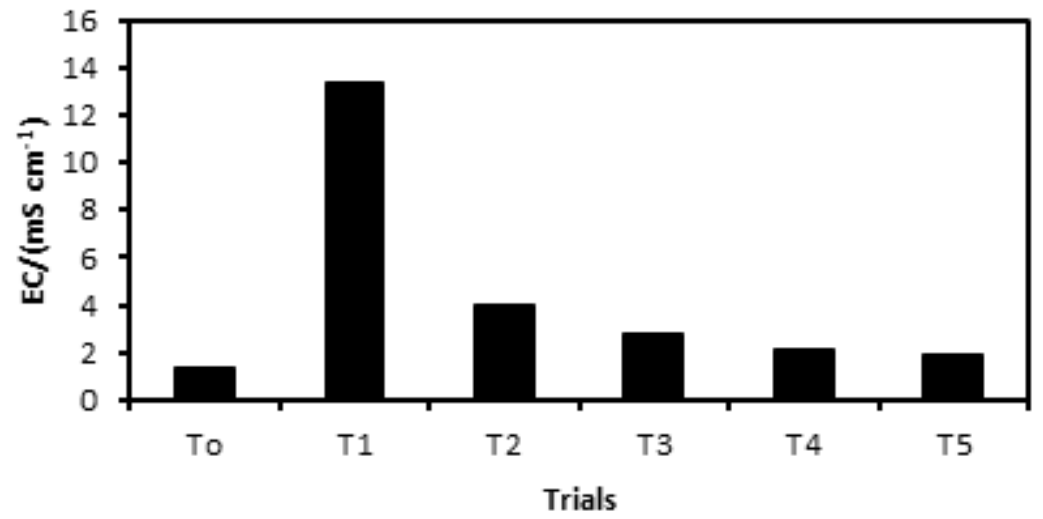

Fig. 4. EC of different trials.

\subsection{Total organic carbon (TOC)}

Total organic carbon (TOC) of the mixtures was in the ranges of $245.5-359.0 \mathrm{mg} \mathrm{g}^{-1}$ dried sample and the order was $\mathrm{T}_{0}>\mathrm{T}_{5}>\mathrm{T}_{4}>\mathrm{T}_{3}>\mathrm{T}_{2}>\mathrm{T}_{1}$ (Table 4). As cow urine is rich in minerals [17], TOC values were decreased with the increase in urine concentration in the mixtures.

\subsection{Macronutrients $(N, P, K)$}

Macronutrients $(\mathrm{N}, \mathrm{P}, \mathrm{K})$ contents of different samples are shown in Table 4 and the data are illustrated in Fig. 5.

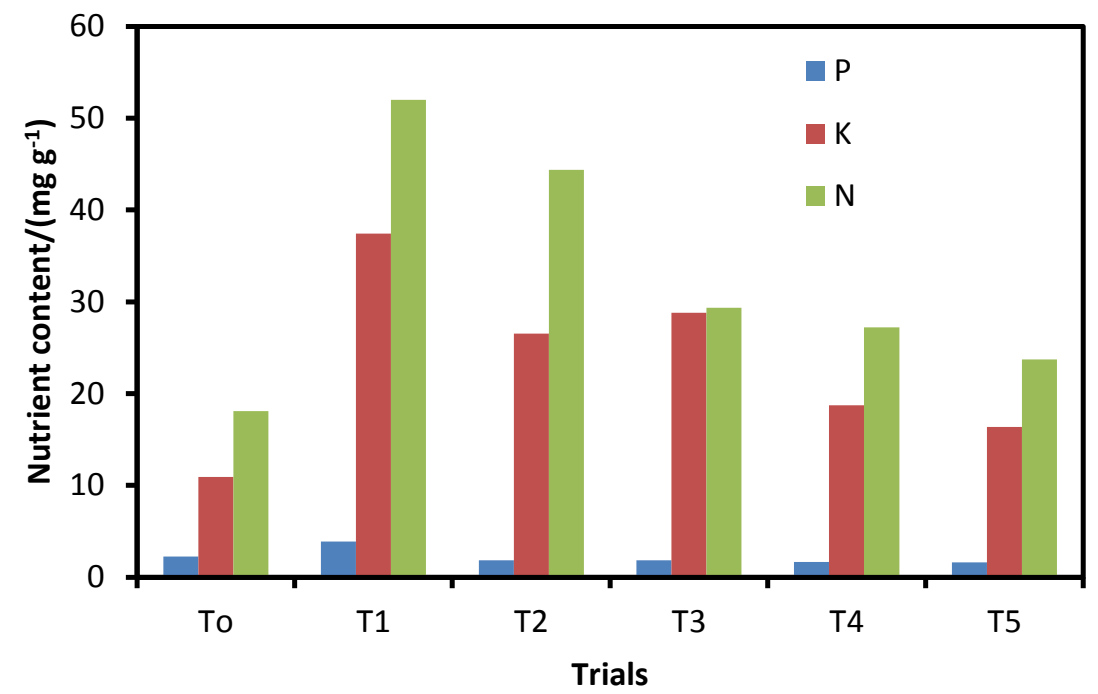

Fig. 5. Nutrient content (N, P, K) in slurries of different trials. 
As cattle urine is rich in nitrogen ranging from 6.8 to $21.6 \mathrm{~g} \mathrm{~L}^{-1}$ [7] its use increases nitrogen content in biogas slurry and accordingly the order total nitrogen was found to be $\mathrm{T}_{1}>\mathrm{T}_{2}>\mathrm{T}_{3}>\mathrm{T}_{4}>\mathrm{T}_{5}>\mathrm{T}_{0}$. N, P, K values of $\mathrm{T}_{0}$ was comparable to the report by S. Suther [18]. Although the value of available $\mathrm{P}$ was not changed appreciably, the value of exchangeable $\mathrm{K}$ was enhanced remarkably with the increase in cow urine proportion. With respect to macronutrient $(\mathrm{N}, \mathrm{P}, \mathrm{K})$ cow urine amended samples can be considered superior to the control one. Moreover, the addition of cow urine decreases $\mathrm{C} / \mathrm{N}$ ratio appreciably. $\mathrm{C} / \mathrm{N}$ ratio of all the amended samples were below 15 (4.7-14.0) and thus these are suitable for agronomic uses of composts [19].

\section{Conclusion}

From this study it can be concluded that utilization of cow urine for biogas production can contribute to the renewable energy by enhancing biogas production and to reduce environmental pollution. Biogas slurry is a good organic fertilizer and utilization of cow urine enriches it with the properties that are quality parameters for an organic fertilizer. Biogas slurry extracts may also be considered as an excellent pest repellent. It may help reducing environmental pollution by replacing toxic chemicals and insecticides. An agrarian country like Bangladesh may get tremendous benefits by utilizing cow urine in biogas production. This is an interesting solution to farming challenges (fertilizer) for smallholder farmers.

\section{Acknowledgment}

The authors are grateful to the Faculty of Science, University of Rajshahi, Bangladesh for providing financial support to carry out this research work.

\section{References}

1. S. Mitra, M. H. Sarkar, and A. K. Majumder, J. Energy and Natural Resources. 6, 64 (2017). https://doi.org/10.11648/j.jenr.20170605.12

2. A. J. Ward, P. J. Hobbs, P. J. Holliman, and D. L. Jones, Bioresour. Technol. 99, 7928 (2008). https://doi.org/10.1016/j.biortech.2008.02.044

3. I. S. Horváth, M. Tabatabaei, K. Karimi, and R. Kumar, Biofuel Res. J. 10, 394 (2016). https://doi.org/10.18331/BRJ2016.3.2.4

4. J. Pagés-Díaz, J. Westman, M. J. Taherzadeh, I. Pereda-Reyes, and I. S. Horváth, Chem. Eng. J. 273, 28 (2015). https://doi.org/10.1016/j.cej.2015.03.049

5. A. Das and C. Mondal, Int. Res. J. Environ. Sci. 5, 49 (2016).

6. M. Eusuf, Mahatabuddin, and M. M. G. Hossain, Bang. J. Sci. Ind. Res. 18, 1 (1983).

7. M. N. A Miah, M. R. U. Miah, and M. Z. Alam, Int. Annals Sci. 3, 23 (2017). https://doi.org/10.21467/ias.3.1.23-26

8. ASTM. Standard Test Methods for Moisture, Ash, and Organic Matter of Peat and Other Organic Soils. Method D 2974-00. American Society for Testing and Materials (West Conshohocken, PA, 2000).

9. B. A. Schumacher, Methods For The Determination of Total Organic Carbon (TOC) in Soils and Sediments (US Environmental Protection Agency, Ecological Risk Assessment Support Centre, National Exposure Research Laboratory, Las Vegas, 2002). 


\section{Cow Urine for Biogas Production and Fertilizer Quality of Biogas Slurry}

10. O. Bojko and C. Kabała, Polish J. Soil Sci. 42, 72 (2014).

11. M. R. Motsara and R. N. Roy, Guide to Laboratory Establishment for Plant Nutrient Analysis, FAO Fertilizer and Plant Nutrition Bulletin19 (Food and agriculture organization of the United Nations, Rome, 2008) pp. 42.

12. S. R. Olsen, C. V. Cole, F. S. Watanabe, and L. A. Dean, Estimation of Available Phosphorus in Soils by Extraction With Sodium Bicarbonate (Circ. US Dept. Agric., 939, 1954).

13. J. G. Ibanez, M. Hemandez-Esparza, C. Doria-Serrano, A. Fregoso-Infante, and M. M. Singh, Environmental Chemistry: Microscale Laboratory Experiments (Springer, New York, 2008). https://doi.org/10.1007/978-0-387-49493-7

14. R. R. Simard, Ammonium Acetate Extractable Element, In: Soil Sampling and Methods of Analysis, ed. R. Martin et al. (Lewis Publisher, Florida, USA, 1993) pp. 39-43.

15. A. K. Mathew, I. Bhui, S. N. Banerjee, R. Goswami, A. Shome, A. K. Chakraborty, S. Balachandran, and S. Chaudhury, Clean Technol. Environ. Policy, 17, 1681 (2014). https://doi.org/10.1007/s10098-014-0877-6

16. M. Seafatullah, M. A. Hoque, M. S. Islam, M. M. Islam, and M. N. Islam, J. Sci. Res. 7, 167 (2015). https://doi.org/10.3329/jsr.v7i3.23756

17. G, Harshad, N. Amit, M. Nilesh, B. Sunanda, and S. Amrut, Int. J. Res. Ayurveda Pharm. 8, 1 (2017). https://doi.org/10.7897/2277-4343.085231

18. S. Suthar, Bioresour. Technol. 100, 6422 (2009). https://doi.org/10.1016/j.biortech.2009.07.004

19. F. M. C. Morais and C. A. C. Queda, Study of Storage Influence on Evolution of Stability and Maturity Properties of MSW Composts - Proc. Fourth Int. Conf. of ORBIT Assoc. on Biological Processing of Organics: Advances for a Sustainable Society (Part II, Perth, Australia). 